Ambiente \& Água - An Interdisciplinary Journal of Applied Science
ISSN 1980-993X - doi:10.4136/1980-993X
www.ambi-agua.net
E-mail: ambi-agua@agro.unitau.br

\title{
Agricultural recycling of biodigested vinasse for lettuce production
}

\author{
doi: 10.4136/ambi-agua.1313
}

Received: 11 Feb. 2014; Accepted: 26 Sep. 2014

\author{
Camila Roberta Javorski Ueno ${ }^{1 *}$; Antonio Carlos Saraiva da Costa ${ }^{2}$; \\ Marcelino Luiz Gimenes ${ }^{3}$; Gisella Maria Zanin ${ }^{3}$ \\ ${ }^{1}$ Universidade Estadual de Maringá (UEM), Maringá, PR, Brasil \\ Programa de Pós-graduação em Agronomia \\ ${ }^{2}$ Universidade Estadual de Maringá (UEM), Maringá, PR, Brasil \\ Departamento de Agronomia \\ ${ }^{3}$ Universidade Estadual de Maringá (UEM), Maringá, PR, Brasil \\ Departamento de Engenharia Química \\ "Corresponding author: e-mail: crjueno@gmail.com, \\ antoniocscosta@gmail.com, marcelino@deq.uem.br, gisella@deq.uem.br
}

\begin{abstract}
The agricultural use of waste products represents an interesting alternative for nutrient cycling. Biodigested vinasse, the final waste product of vinasse biodigestion and biogas production, can be reused for agricultural purposes. The present work sought to quantify the shoot dry mass production of lettuce plants, as well as foliar nitrogen, phosphorus and potassium content following the application of biodigested vinasse on soil. Biodigested vinasse was produced from anaerobic vinasse digestion, using anaerobic sludge as a source of microorganisms. The treatments, with four replications in entirely randomized design, consisted of anaerobic sludge from a gelatin factory, vinasse in natura, biodigested vinasse and a control treatment. The experiment was conducted over 45 days using $5 \mathrm{~L}$ vases and applying a dose equivalent to $150 \mathrm{~m}^{3} \mathrm{ha}^{-1}$. Lettuce treated with biodigested vinasse showed higher shoot dry mass production and higher accumulation of nitrogen, phosphorus and potassium in its leaves than that treated with vinasse in natura.
\end{abstract}

Keywords: biomass, Lactuca sativa, nutrients, residue, stillage, wastewater.

\section{Reciclagem agrícola de vinhaça biodigerida para produção de alface}

\section{RESUMO}

O uso agrícola de resíduos é uma alternativa interessante para ciclagem de nutrientes. A vinhaça biodigerida, gerada após o processo de sua biodigestão e produção de biogás, permite o reuso agrícola. O presente trabalho quantificou a produção de massa seca da parte aérea em plantas de alface, assim como o acúmulo foliar de nitrogênio, fósforo e potássio após aplicação de vinhaça biodigerida no solo. Os tratamentos, com quatro repetições em um delineamento inteiramente casualizado, utilizaram lodo anaeróbio de indústria de gelatina, vinhaça in natura, vinhaça biodigerida, além de tratamento testemunha. Foi aplicada a dose equivalente a $150 \mathrm{~m}^{3} \mathrm{ha}^{-1}$ em vasos com capacidade para $5 \mathrm{~L}$, sendo o experimento conduzido por 45 dias nos vasos. A vinhaça biodigerida foi produzida a partir da biodigestão anaeróbia de vinhaça, utilizando lodo anaeróbio de indústria de gelatina como fonte de 
micro-organismos. Tratamentos com vinhaça biodigerida demonstraram melhores índices de produção de massa seca da parte aérea e acúmulo de nitrogênio, fósforo e potássio em folhas do que tratamentos utilizando vinhaça in natura.

Palavras-chave: água residuária, biomassa, Lactuca sativa, nutrientes, resíduo, vinhoto.

\section{INTRODUCTION}

In Brazil, the most common final use of vinasse is in crop fertigation, where it is used to meet potassium fertilization requirements and to contribute other essential nutrients. Biogas production has emerged as an additional alternative use of vinasse, with a dual purpose: bioenergy production and production of a waste with fertilization potential.

The beneficial effects of vinasse in agricultural crops are already well known, and studies on vinasse biodigestion have already been performed by several authors, among them Cabello et al. (2009) and Szymanski et al. (2010).

Vinasse biodigestion requires sources of microorganisms for inoculation, such as sludge. The benefits of sludge were evaluated by Chiba (2005), applying $16 \mathrm{tha}^{-1}$ of sewage sludge to ratoon cane, in combination with nitrogen fertilizer. The conclusion was that sludge can replace $100 \%$ of nitrogen fertilizer, thus emphasizing the usefulness of sludge in agriculture. In a study by Almeida et al. (2012), the addition of sewage sludge as fertilizer in soil increased the concentrations of $\mathrm{Fe}, \mathrm{Zn}, \mathrm{Cu}, \mathrm{K}, \mathrm{P}$ and organic matter in the soil, favoring the growth of lettuce plants.

Barros et al. (2011) studied the soil application of biosolids treated anaerobically in a UASB (Upflow Anaerobic Sludge Blanket) reactor, and observed an increase in macronutrient levels in the shoot of plants and in the dry matter in corn plants. Moreover, Gajdos et al. (2012) also observed the positive effects of the application of biofertilizers on corn and sunflower dry matter nutrition and production.

Lettuce is a short-cycle annual vegetable, with large leaves and rapid growth. It adapts best to lower temperatures, requiring wide temperature variations and high relative humidity (Cermeño, 1990). According to Simeoni et al. (1984), rapid-growth leafy plants such as lettuce tend to accumulate more metals than grains, leguminous grasses and vegetable crops; however, phosphorus and potassium deficiency can reduce lettuce plant growth (Gadelha et al., 2003). Santos et al. (2010) observed improved performance in crop physiological attributes such as photosynthesis, transpiration, carboxylation efficiency and chlorophyll levels in treatments with higher doses of vinasse in a basic mixture as substrate.

Faced with the lack of works evaluating the effects of biodigested vinasse in agricultural crops, the objective of the present work was to assess its effect in dry matter production and accumulation of nitrogen, phosphorus and potassium in lettuce plants.

\section{MATERIAL AND METHODS}

The experiment was conducted in a greenhouse located at $23^{\circ} 25^{\prime} \mathrm{S}, 51^{\circ} 57^{\prime} \mathrm{W}$, elevation $542 \mathrm{~m}$. The soil used was Dystrophic Red Latosol (EMBRAPA, 2006) collected at an agricultural area located in Iguatemi - PR, at the 0 and $20 \mathrm{~cm}$ depths.

The soil is derived from Caiuá sandstone, and usually occurs in the toposequence associations with Ultisols and Entisols (EMBRAPA, 2006). The mineralogy of this soil is dominated by quartz in the sand fraction and by kaolinite and hematite in the clay fraction. Other minerals detected by $\mathrm{x}$-ray diffraction include muscovite and anatase in the sand fraction and maghemite and gibbsite in the clay fraction (Souza Júnior et al., 2010).

The soil was crushed and sieved through $2 \mathrm{~mm}$ mesh screens. The soil was then transferred to a $5 \mathrm{~L}$ flask. The soil was later chemically characterized and the calcium, 
magnesium and aluminum contents were extracted with $\mathrm{KCl} 1 \mathrm{~mol} \mathrm{~L}^{-1}$; phosphorus and potassium were extracted by Mehlich 1; hydrogen and aluminum were extracted by the SMP method; and carbon was extracted by the Walkley \& Black method. The methods are described in EMBRAPA (2009). The results can be seen in Table 1.

After the characterization, the soil received dolomitic limestone in order to reach $70 \%$ base saturation, based on data from the initial chemical analysis (Table 1). A total of $2.59 \mathrm{t} \mathrm{ha}^{-1}$ dolomitic limestone with $85 \%$ TNRP was required for soil correction.

Table 1. Particle size and chemical attributes of the Dystrophic Red Latosol.

\begin{tabular}{lc}
\hline \multicolumn{1}{c}{ Parameter } & Result \\
\hline $\mathrm{pH}\left(\mathrm{CaCl}_{2}\right)$ & 4.3 \\
$\mathrm{Ca}^{2+}\left(\mathrm{cmol}_{\mathrm{c}} \mathrm{dm}^{-3}\right)$ & 0.77 \\
$\mathrm{Mg}^{2+}\left(\mathrm{cmol}_{\mathrm{c}} \mathrm{dm}^{-3}\right)$ & 0.33 \\
$\mathrm{~K}^{+}\left(\mathrm{cmol}_{\mathrm{c}} \mathrm{dm}^{-3}\right)$ & 0.15 \\
$\mathrm{SB}\left(\mathrm{cmol}_{\mathrm{c}} \mathrm{dm}^{-3}\right)$ & 1.25 \\
$\mathrm{CEC}\left(\mathrm{cmol}_{\mathrm{c}} \mathrm{dm}^{-3}\right)$ & 4.93 \\
$\mathrm{P}\left(\mathrm{mg} \mathrm{dm}^{-3}\right)$ & 2.2 \\
$\mathrm{C}\left(\mathrm{g} \mathrm{dm}^{-3}\right)$ & 4.99 \\
$\mathrm{~N}\left(\mathrm{~g} \mathrm{~kg}^{-1}\right)$ & 0.6 \\
$\mathrm{Sand}\left(\mathrm{g} \mathrm{kg}^{-1}\right)$ & 670 \\
$\mathrm{Silt}\left(\mathrm{g} \mathrm{kg}^{-1}\right)$ & 10 \\
Clay $\left(\mathrm{g} \mathrm{kg}^{-1}\right)$ & 320 \\
Silt / Clay Ratio & 0.031 \\
\hline
\end{tabular}

Note: $\mathrm{Ca}, \mathrm{Mg}$ - extracted with $\mathrm{KCl} 1 \mathrm{~mol} \mathrm{~L}^{-1}, \mathrm{P}$, $\mathrm{K}$ - extracted with Mehlich 1, C - method Walkley \& Black (EMBRAPA, 2009); SB - sum of bases; CEC - cation exchange capacity.

The initial biodigested material consisted of a mixture of $80 \%$ vinasse from an ethanol plant and 20\% liquid anaerobic sludge from a gelatin factory, both located in the region of Maringá-PR. The sludge was used as source of microorganisms for anaerobic vinasse biodigestion. The materials were kept in sealed Erlenmeyer flasks. Biodigestion took place for 20 days, at $30^{\circ} \mathrm{C}$ and continuous agitation at $150 \mathrm{rpm}$, using an agitator under controlled temperature. Later, the sludge, vinasse and biodigested vinasse were chemically characterized and the $\mathrm{Ca}$ and $\mathrm{Mg}$ were extracted with $\mathrm{KCl} 1 \mathrm{~mol} \mathrm{~L}^{-1}, \mathrm{P}$ and $\mathrm{K}$ were extracted with Mehlich 1, and the Walkley \& Black method was used to determine C (EMBRAPA, 2009).

No chemical fertilizers were added to the soil for lettuce cultivation - only biodigested vinasse. Following fertigation, there was a 30-day incubation period before transplanting the seedlings of iceberg lettuce (Lactuca sativa), produced in Styrofoam trays with an organic substrate made from pine bark. The 30-day-old seedlings were then transplanted, one per vase, and grown for 45 days under daily irrigation.

The experimental design chosen was entirely randomized, with four replications. The vinasse dosage used was $375 \mathrm{~mL}$, equivalent to $150 \mathrm{~m}^{3} \mathrm{ha}^{-1}$. Four treatments were tested: a control, vinasse, sludge and biodigested vinasse. The treatment with sludge sought to evaluate the sludge's ability to improve crop production, given that biodigested vinasse included $20 \%$ sludge in its formation. 
After 45 days of cultivation, the plants were harvested and the shoot dry mass was determined. To that end, the material was cleansed in running water to remove rough and undesired materials, and then stored in pre-weighed paper bags. The material was then taken to a forced-air oven at $60-70^{\circ} \mathrm{C}$, until constant weight. Next, the paper bags were transferred to a desiccator until completely cooled, followed by weighing of the dry mass of the shoot.

Chemical analyses were conducted on the leaves in order to quantify the nitrogen $(\mathrm{N})$, phosphorus $(\mathrm{P})$ and potassium $(\mathrm{K})$ contents according to the methodology proposed by Malavolta (1997). After being oven-dried at $60-70^{\circ} \mathrm{C}$, the leaves were ground by passing all materials through a $2 \mathrm{~mm}$ mesh sieve. Total nitrogen was determined by the classic Kjeldahl method, phosphorus and potassium were determined by UV/Vis and atomic absorption spectrophotometry of the extracts of the nitro-prechloric digestion, respectively.

The results were statistically analyzed using SAS software (SAS, 1999). Means were compared using Tukey's test, at a 5\% significance level. Multiple regression analyses for estimating dry matter yield of shoot in the treatments was performed using the Stepwise routine of SAS software (SAS, 1999), at a 5\% significance level.

\section{RESULTS AND DISCUSSION}

The chemical attributes and major nutrients added to the soil by the different wastes are shown in Table 2.

Table 2. Values of $\mathrm{pH}$ and nutrient content of the wastes to be added to the soil.

\begin{tabular}{lccc}
\hline Parameter & $\mathbf{S}^{\mathbf{I}}$ & $\mathbf{V}^{\text {II }}$ & $\mathbf{B V}^{\mathbf{I I}}$ \\
\hline $\mathrm{pH}\left(\mathrm{H}_{2} \mathrm{O}\right)$ & 7.00 & 5.02 & 6.74 \\
Organic Matter $\left(\mathrm{g} \mathrm{L}^{-1}\right)$ & 49.64 & 26.80 & 3.55 \\
$\mathrm{~N}\left(\mathrm{~g} \mathrm{~L}^{-1}\right)$ & 7.00 & 2.38 & 1.26 \\
$\mathrm{C} / \mathrm{N} \mathrm{Ratio}$ & $4: 1$ & $6: 1$ & $2: 1$ \\
$\mathrm{CaO}\left(\mathrm{mg} \mathrm{L}^{-1}\right)$ & 3153 & 2823 & 2218 \\
$\mathrm{MgO}\left(\mathrm{mg} \mathrm{L}^{-1}\right)$ & 345 & 1616 & 1296 \\
$\mathrm{~K}_{2} \mathrm{O}\left(\mathrm{mg} \mathrm{L}^{-1}\right)$ & 853 & 3927 & 3640 \\
$\mathrm{P}_{2} \mathrm{O}_{5}\left(\mathrm{mg} \mathrm{L}^{-1}\right)$ & 796.0 & 127.3 & 199.0 \\
\hline
\end{tabular}

Note: ${ }^{\text {I }}$ Sludge; ${ }^{\text {II }}$ Vinasse; ${ }^{\text {III }}$ Biodigested vinasse

$\mathrm{Ca}, \mathrm{Mg}$ - extracted with $\mathrm{KCl} 1 \mathrm{~mol} \mathrm{~L}^{-1}, \mathrm{P}, \mathrm{K}$ - extracted with Mehlich 1, C - method Walkley \& Black (EMBRAPA, 2009).

The nutrients present in the biodigested vinasse treatment (Table 2) do not correspond to the sum of $80 \%$ vinasse plus $20 \%$ sludge, thus evidencing that the presence of sludge in the mixture was important for the positive and significant response in the treatments with sludge or biodigested vinasse.

The relatively high losses of $\mathrm{C}$ and $\mathrm{N}$ during the mineralization of the combination of sludge + vinasse were compensated by very high accumulation of phosphate and potassium and the other secondary macronutrients $(\mathrm{CaO}, \mathrm{MgO})$.

A reduction in nutrient levels and in the $\mathrm{C} / \mathrm{N}$ ratio can be observed in biodigested vinasse compared to vinasse in natura and sludge. This is due mainly to the hydrolysis reactions that took place in the first stage of the anaerobic processes, in which the nutrients are hydrolyzed and solubilized. When water passes through the mass of solid organic waste, it carries dissolved nutrients along with it by lixiviation, thus decreasing their levels after biodigestion. 
Organic materials with a lower $\mathrm{C} / \mathrm{N}$ ratio lead to faster nutrient release (Kiehl, 1998), providing better growth conditions for short-cycle plants, as in the case of lettuce, and can increase moisture retention (Araújo et al., 2008).

There were statistically significant differences $(p<0.05)$ in the biomass production from the shoots when comparing the treatments.

The accumulation of biomass from the lettuce plant shoots subjected to the treatment with added sludge (Table 3) showed the best results for the dry mass productions from the shoot. The high shoot yield in the sludge treatment is due to the superior balance in the chemical attributes of that waste compared to the others (Table 2). The incorporation of organic waste added high levels of nutrients $(\mathrm{N}, \mathrm{P}, \mathrm{K}, \mathrm{Ca}$ and $\mathrm{Mg}$ ) to the soil, complexed to the organic forms of the wastes and available for absorption by the root system of lettuce plants (Lopes et al., 2005). These complexes, barely found in the original soil, doubled shoot yield compared to the control treatment.

The biodigested vinasse resulted in significantly positive $(p<0.05)$ increases in dry mass shoot (DMS) production as it improved vinasse chemical attributes, providing nutrients, balancing existing biological activity and reducing the impact of salinity of that waste product, which is rich in potassium and other salts (Table 2).

Following the anaerobic digestion of cattle manure, Costa et al. (2006) observed positive interactions on fresh phytomass of the shoot with the use of biofertilizers in the production of two lettuce cultivars.

Ortega e Cazetta (2011), recommend biodigested vinasse concentrate for sugarcane crops as it showed no significant differences in plant growth compared to vinasse in natura.

Franklin (2004) observed that differences in the treatment systems, such as the stabilization procedure used, percentages of $\mathrm{N}^{-\mathrm{NO}_{3}}{ }^{-}$and $\mathrm{N}-\mathrm{NH}_{4}{ }^{+}$, and method of application to the soil (dry, moist), affect the percentage of available $\mathrm{N}$.

Notwithstanding this, the dry mass values are lower than those found by some authors (Martins et al., 2009; Lopes et al., 2005); however, the growing season (warm months) justifies the low yield (Viggiano, 1990). The intense heat particularly affected the control treatment, which featured approximately half the values of the sludge and biodigested vinasse treatments.

The positive response in dry matter production in the shoot of lettuce plants grown with biodigested vinasse, when compared to control treatment and vinasse in natura, is related to the process of biodigestion undergone in vinasse. The active microorganisms in the biodigestion process make nutrients more easily absorbable for plants. In the anaerobic biodigestion of goat waste, Orrico et al. (2011) observed that increasing the amount of concentrate in the animal diet resulted in more absorbable substrates after anaerobic biodigestion, which favored the development of anaerobic microorganisms, thus facilitating the reduction of organic material and biogas production.

With regard to the accumulation of nitrogen, phosphorus and potassium in lettuce leaves, significant differences $(p<0.05)$ were observed resulting from the application of waste on soil (Table 3). The biodigested vinasse treatment significantly favored the accumulation of nitrogen, phosphorus and potassium compared to the other treatments.

The treatment with biodigested vinasse showed significantly higher levels of $\mathrm{N}, \mathrm{P}$ and $\mathrm{K}$ in the plant leaves (Table 3). With the exception of phosphorus, the treatment with added vinasse in natura in soil showed significantly higher amounts of nitrogen and potassium than treatments with added sludge. The control treatment showed the smallest values for all nutrients, but was statistically similar $(p<0.05)$ for nitrogen levels when compared to the treatment with sludge, and resulted in the lowest nutrient levels in the shoot of plants. Therefore, it was not the amount of nitrogen added to the soil via sludge, but rather the amounts of the other nutrients (phosphorus, potassium, calcium and magnesium), biological 
activity and various forms of $\mathrm{N}$ that determined the significant differences (Table 3 ) in DMS yield when compared to the control treatment.

Table 3. Biomass from lettuce plant shoots and accumulation of nitrogen $(\mathrm{N})$, phosphorus $(\mathrm{P})$ and potassium (K).

\begin{tabular}{lccccc}
\hline \multirow{2}{*}{ Treatment } & Shoot & & $\mathbf{N}$ & $\mathbf{P}$ & $\mathbf{K}$ \\
\cline { 2 - 4 } \cline { 4 - 6 } & g plant $^{-1}$ & & & $\mathbf{g ~ k g}^{-1}$ & \\
\hline Sludge & $5.86 \pm 0.80^{*} \mathrm{a}$ & & $16.68 \pm 0.32^{*} \mathrm{c}$ & $1.90 \pm 0.01^{*} \mathrm{~b}$ & $19.97 \pm 0.12^{*} \mathrm{c}$ \\
Vinasse in natura & $4.75 \pm 0.17^{*} \mathrm{c}$ & & $24.26 \pm 0.28^{*} \mathrm{~b}$ & $1.80 \pm 0.02^{*} \mathrm{c}$ & $23.87 \pm 0.16^{*} \mathrm{~b}$ \\
Biodigested vinasse & $5.25 \pm 0.04^{*} \mathrm{~b}$ & & $51.17 \pm 0.37^{*} \mathrm{a}$ & $2.13 \pm 0.02^{*} \mathrm{a}$ & $24.53 \pm 0.06^{*} \mathrm{a}$ \\
Control & $2.66 \pm 0.49^{*} \mathrm{~d}$ & & $16.14 \pm 0.15^{*} \mathrm{c}$ & $1.64 \pm 0.02^{*} \mathrm{~d}$ & $15.57 \pm 0.55^{*} \mathrm{~d}$ \\
\hline
\end{tabular}

Note: * Average value \pm standard deviation.

Letters in the same column mean significant difference $(\mathrm{p}<0.05)$ among treatments.

The amount of absorbed nitrogen, phosphorus and potassium were smaller than the values observed in the literature (Martins et al., 2009; Almeida Júnior et al., 2011) due to the warmer conditions as observed previously (Viggiano, 1990).

Higher values of $\mathrm{P}$ and $\mathrm{K}$ in the leaves of lettuce fertilized with organic compounds were observed by Rodrigues and Casali (1998), and by García-Martínez et al. (2009) in tomato cultivation. Camilotti et al. (2006) determined that sewage sludge as a source of $\mathrm{N}$ and vinasse as a source of $\mathrm{K}$ were efficient sources of these minerals, and resulted in increased yields and higher industrial quality of third and fourth ratoon cane.

The low $\mathrm{C} / \mathrm{N}$ ratio of all waste treatments might have contributed to better nutrient accumulation, smaller than 18:1 (Kiehl, 1998).

Thus, biodigested vinasse, which contains sludge and vinasse in its composition, significantly contributes as a source of $\mathrm{N}$ from sludge, and $\mathrm{P}$ and $\mathrm{K}$ from vinasse.

Multiple regression analyses were performed for the variable DMS regarding the different chemical attributes of the soil and plants, in selected treatment clusters (Table 4), using the Stepwise routine of SAS software (SAS, 1999). Potassium was the only dependent variable chooser when the multiple regression equation considered the control $\mathrm{x}$ vinasse $\mathrm{x}$ biodigested vinasse treatments. For the control x sludge treatments, however, no independent variable contributed to DMS at a $5 \%$ probability level. When the vinasse $\mathrm{x}$ biodigested vinasse treatments were used, the independent variable CEC was positively correlated to the DMS.

The multiple regression equations confirmed previous observations, demonstrating that the contribution of vinasse to soil potassium levels was essential for DMS accumulation (Camilotti et al., 2006). With regard to the mixture of vinasse and sludge, the greater contribution comes from sludge, which might have favored the accumulation of organic colloids and significantly increased soil CEC, and consequently DMS yield (Kiehl, 1998).

Table 4. Multiple regression analyses for estimating dry matter yield of shoot in the treatments.

\begin{tabular}{llcc}
\hline Treatments considered & \multicolumn{1}{c}{ Equation } & $\mathbf{R}^{\mathbf{2}}$ & P \\
\hline Control x V x BV & $\mathrm{Y}=-1.59999+0.2728 * \mathrm{~K}$ folha & 0.94 & $<0.0001$ \\
Control x S & There was no equation & Not significant & \\
V x BV & $\mathrm{Y}=-3.56524+0.0029 *$ CEC & 0.92 & 0.0002 \\
\hline
\end{tabular}

Note: $\mathrm{V}=$ vinasse $\mathrm{BV}=$ Biodigested vinasse. 


\section{CONCLUSIONS}

The absorption of the nutrients nitrogen, phosphorus and potassium in lettuce leaves was significantly greater in the treatment with biodigested vinasse. In the sludge treatment, nitrogen levels in the plants were statistically equal to the control treatment, despite greater DMS yield. Phosphorus and potassium accumulated in the leaves were determining factors for DMS production.

\section{ACKNOWLEDGEMENTS}

This study was supported by the Coordination for the Improvement of Higher Education Personnel (CAPES).

\section{REFERENCES}

ALMEIDA JÚNIOR, A. B.; NASCIMENTO, C. W. A.; SOBRAL, M. F.; SILVA, F. B. V.; GOMES, E. A. Fertilidade do solo e absorção de nutrientes em cana-de-açúcar fertilizada com torta de filtro. Revista Brasileira de Engenharia Agrícola e Ambiental, v. 15, p. 1004-1013, 2011. http://dx.doi.org/10.1590/S141543662011001000003

ALMEIDA, V. C.; SODRÉ, F. F.; VARGAS, A. M. M.; BUKMAN, L.; MARTINS, A. C.; MORAES, J. C. G. et al. Phytotoxicity and distribution of copper in tropical soil amended with sewage sludge and copper sulfate. Chemical Speciation and Bioavailability, v. 24, p. 97-104, 2012. http://dx.doi.org/10.3184/095422912X13334505546124

ARAÚJO, F. F.; TIRITAN, C. S.; FOLONI, J. S. S. Utilização de compostos orgânicos semicurados na produção de alface (Lactuca sativa). Revista Caatinga, v. 21, p. 113$117,2008$.

BARROS, I. T.; ANDREOLI, C. V.; SOUZA JÚNIOR, I. G.; COSTA, A. C. S. Avaliação agronômica de biossólidos tratados por diferentes métodos químicos para aplicação na cultura do milho. Revista Brasileira de Engenharia Agrícola e Ambiental, v. 15, p. 630-638, 2011. http://dx.doi.org/10.1590/S1415-43662011000600014

CABEllo, P. E.; SCOGNAMiglio, F. P.; TERÁN, F. J. C. Tratamento de vinhaça em reator anaeróbio de leito fluidizado. Engenharia Ambiental, v. 6, p. 321-338, 2009.

CAMILOTTI, F.; ANDRIOLI, I.; MARQUES, M. O.; SILVA, A. R.; TASSO JUNIOR, L.C.; NOBILE, F. O. et al. Produtividade e qualidade agroindustrial da cana-de-açúcar cultivada com lodo de esgoto, vinhaça e adubos minerais. STAB: Açúcar, Álcool e Subprodutos, v. 24, p. 32-35, 2006.

CERMEÑO, Z. S. Estufas: instalações e manejo. Lisboa: Litexa, 1990.

COSTA, N. E.; RIBEIRO, M. C. C.; LIMA, J. S. S.; CARDOSO, A. A.; OLIVEIRA, G. L. Utilização de biofertilizante na alface para o sistema hidropônico floating. Revista Verde de Agroecologia e Desenvolvimento Sustentável, v. 1, p. 41-47, 2006.

CHIBA, M. K. Uso de lodo de esgoto na cana-de-açúcar como fonte de nitrogênio e fósforo:parâmetros de fertilidade do solo, nutrição da planta e rendimentos da cultura. 2005. 142f. Tese (Doutorado) - Escola Superior de Agricultura Luiz de Queiroz, Piracicaba, 2005. 
EMPRESA BRASILEIRA DE PESQUISA AGROPECUÁRIA - EMBRAPA. Centro Nacional de Pesquisa de Solos. Sistema brasileiro de classificação de solos. Rio de Janeiro: Embrapa CNPS, 2006.

EMPRESA BRASILEIRA DE PESQUISA AGROPECUÁRIA - EMBRAPA. Manual de análises químicas de solos, plantas e fertilizantes. 2. ed. Brasília, DF: Embrapa Informação Tecnológica, 2009.

FRANKLIN, R. Land application of sewage sludge. Clemson: Clemson University, Faculty of Soils and Land Resources. 2004.16 p.

GADELHA R. S. S.; CELESTINO R. C. A.; SHIMOYA, A. Efeito da utilização de urina de vaca na produção da alface. Pesquisa Agropecuária \& Desenvolvimento Sustentável, v. 1, p. 179-182, 2003.

GAJDOS, E.; LÉVAI, L.; VERES, S.; KOVÁCS, B. Effects of biofertilizers on maize and sunflower seedlings under cadmium stress. Communications in Soil Science and Plant Analysis, v. 43, p. 272-279, 2012. http://dx.doi.org/10.1080/00103624.2011.638591

GARCÍA-MARTÍNEZ, S.; GRAU, A.; AGULló, E.; BUSTAMANTE, M. A.; PAREDES, C.; MORAL, R. et al. Use of composts derived from winery wastes in tomato crop. Communications in Soil Science and Plant Analysis, v. 40, p. 445-452, 2009. http://dx.doi.org/10.1080/00103620802695099

KIEHL, E. J. Manual de compostagem: maturação e qualidade do composto. Piracicaba: E. J. Kiehl, 1998.

LOPES, J. C.; RIBEIRO, L. G.; ARAÚJO, M. G.; BERALDO, M. R. B. S. Produção de alface com doses de lodo de esgoto. Horticultura Brasileira, v. 23, p. 143-147, 2005. http://dx.doi.org/10.1590/S0102-05362005000100030

MALAVOLTA, E. Avaliação nutricional das plantas: princípios e aplicação. 2. ed. Piracicaba: [s.n.],1997.

MARTINS, C. M.; MEDEIROS, J. F.; LOPES, W. A. R.; BRAGA, D. F.; AMORIM, L. B. Curva de absorção de nutrientes em alface hidropônica. Revista Caatinga, v. 22, p. 123-128, 2009.

ORRICO, A. C. A.; ORRICO JÚNIOR, M. A. P.; DE LUCAS JÚNIOR, J. Biodigestão anaeróbia dos dejetos de cabritos Saanem alimentados com dietas com diferentes proporções volumoso e concentrado. Revista Brasileira de Zootecnia, v. 40, p. 448453, 2011. http://dx.doi.org/10.1590/S1516-35982011000200029

ORTEGA, K.; CAZETTA, J. O. Crescimento inicial de planta de cana-de-açúcar fertilizada com concentrado de vinhaça biodigerida. Suplemento Ciência \& Tecnologia: FATEC-JB, Jaboticabal, v. 3, 2011.

RODRIGUES, E. T.; CASALI, V. W. Resposta da alface à adubação orgânica. II. Teores, conteúdos e utilização de macronutrientes em cultivares. Revista Ceres, v. 45, p. 437449, 1998.

SANTOS, C. M.; GONÇALVES, E. R.; ENDRES, L.; GOMES, T. C. A.; JADOSKI, C. J.; NASCIMENTO, L. A. et al. Atividade fotossintética em alface (Lactuca sativa L.) submetidas a diferentes compostagens de resíduos agroindustriais. Pesquisa Aplicada \& Agrotecnologia, v. 3, n. 3, p. 95-102, 2010. 
STATISTICAL ANALYSIS SYSTEM INSTITUTE. SAS/STAT Procedure guide for personal computer. Version 5. Cary, NC, 1999.

SIMEONI, L. A.; BRABARICK, K. A.; SABEY, B. R. Effect of a small-scale composting of sewage sludge on heavy metal availability to plants. Journal Environmental Quality, v. 13, n. 2, p. 264-268, 1984.

http://dx.doi.org/10.2134/jeq1984.00472425001300020018x

SOUZA JÚNIOR, I. G.; COSTA, A. C. S.; VILAR, C. C.; HOEPERS, A. Mineralogia e susceptibilidade magnética dos óxidos de ferro do horizonte $\mathrm{B}$ de solos do Estado do Paraná. Ciência Rural, v. 40, n. 3, p. 513-519, 2010. http://dx.doi.org/10.1590/S010384782010000300003

SZYMANSKI, M. S. E.; BALBINOT, R.; NAGEL, W. Biodigestão anaeróbia da vinhaça: aproveitamento energético do biogás e obtenção de créditos de carbono - estudo de caso. Revista Semina: Ciências agrárias, v. 31, n. 4, p. 901-912, 2010. http://dx.doi.org/10.5433/1679-0359.2010v31n4p901

VIGGIANO, J. Produção de sementes de alface. In: CASTELLANE, P. D.; NICOLOSI, W. M.; HASEGAWA, M. (Coord.). Produção de sementes de hortaliças. Jaboticabal: FCAV/FUNEP, 1990. p. 1-13. 